\title{
Hogan remedy for provincial health woes 'ignored'
}

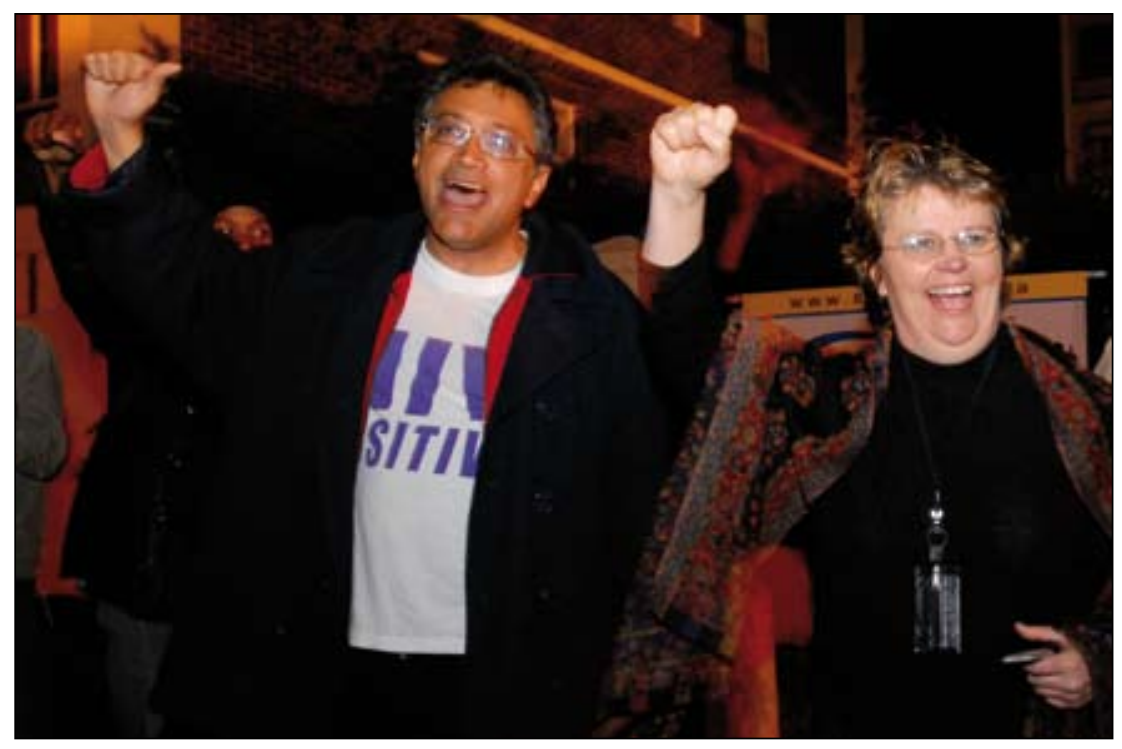

New Health Minister Barbara Hogan shows solidarity with triumphant TAC stalwart, Zackie Achmat, hours after her appointment in 2008.

A comprehensive blueprint for rehabilitating provincial health departments, drawn up during the brief tenure of former national health minister, Barbara Hogan, is being largely ignored by the current health leadership regime.

This claim emerged in a critique of the health component of Finance Minister Pravin Gordhan's budget speech this February by the widely respected NGOs, Section 27 and the Treatment Action Campaign (TAC). Chief among their concerns about the efficacy of the R11 billion boost to the $2011 / 2012$ health budget is the lack of a reasonable plan to address endemic and systemic problems' of budgeting and spending within provincial health departments and their national counterpart.

\section{'It's difficult to determine} precisely what health service is being delivered, what needs to be delivered and what it will cost without aligning health needs and priorities to budgets.'

Said Daygan Eager, a spokesperson for the two NGOs, 'It's difficult to determine precisely what health service is being delivered, what needs to be delivered and what it will cost without aligning health needs and priorities to budgets. When Izindaba probed this observation, the existence of the
'Hogan blueprint' emerged - an exhaustive report by some of the country's top health experts into dysfunctional provinces, complete with turnaround plans. The report was leaked to Section 27 (formerly the AIDS Law Project) and the Rural Health Advocacy Project in September last year, followed by the reluctant official release of a consolidated 'across provinces' report with overarching findings. ${ }^{1}$

'The problem with that [report] is that it doesn't speak to the context-specific issues within each provincial department,' complained Eager. He said his understanding was that the public release of the full Hogancommissioned report was delayed because the health ministry wanted to first distribute it to heads of departments and Health MECs to see how they'd integrate it into their strategic plans.

'Basically they sat on it. Since then I've seen very little indication that those reports are being used in addressing problems in any provinces except the Eastern Cape,' he added.

\section{'Top loading' of senior management}

One of the key recommendations in the Hogan report is to overhaul organisational structures and account for the use of funds, especially those used to 'top-load' administrations at senior management level. It found that provinces duplicated tasks and senior managers were ignorant of what their counterparts were doing. The Eastern Cape responded positively, shifting funding to facility level, thus enabling vital 'point of service' delivery. This was in marked contrast to Gauteng, where the Gauteng Shared Service Centre (GSSC), micro- (and mostly mis-) manages every health care facility's financial and thus procurement needs. ${ }^{2}$

The Hogan report offers an honest and grim assessment of failing financial management, human resource and monitoring and evaluation systems and highlights a failure of leadership from the national department of health $(\mathrm{NDoH})$ under its former Director-General Thami Mseleku.

The Hogan report offers an honest and grim assessment of failing financial management, human resource and monitoring and evaluation systems and highlights a failure of leadership from the national department of health $(\mathrm{NDoH})$ under its former Director-General Thami Mseleku.

It documents failures by the provincial departments of health and finance, the $\mathrm{NDoH}$ and National Treasury to take appropriate action as provincial health departments accumulated debts starting in the 2006/2007 financial year. This debt rose to R7.5 billion by 1 April 2009, with financial management of all departments 'characterised by a lack of transparency'.

Section 27 and the TAC at the time called for all those responsible for 'corrupt, wasteful and inefficient expenditure at all levels' to be brought to book, held accountable and barred from working in the public service. All allegations of corruption against MECs and heads of Health should be probed and those who are guilty prosecuted (there have been and still are several underway, many of which have ended up in the criminal courts).

The two NGOs described the Hogan report as 'a blueprint for rectifying the system'.

The two NGOs described the Hogan report as 'a blueprint for rectifying the system?. Its top recommendations included: 
- The need to accurately determine the exact amount of the financial backlogs in each province, with the $\mathrm{NDoH}$ chief financial officer taking the lead.

- Accurate costing and guaranteed funding from a properly determined baseline budget before public policy announcements were made about the implementation of new health programmes.

- That the Minister of Health drive the development of one national health vision and strategy, with the involvement and participation of the provincial health MECs, health departments and other stakeholders.

- That there should be alignment between the national vision and strategy, programme strategic plans and annual national health plan, as well as between targets and interventions within the $\mathrm{NDoH}$. All plans should pay more attention to implementation, be aligned with each other and contain a clear monitoring and evaluation framework with performance targets.

- That proposed new structures be carefully reviewed and restructuring, with a view to establishing minimum staffing levels and optimal management and administrative positions, be undertaken based on objectively agreed benchmarks, optimal application of scarce skills, the public health sector's strategic and service delivery priorities and resource availability.

- That a moratorium on the establishment of additional provincial head office positions be considered until the review was concluded.

\section{Health Minister implements some recommendations}

To national health minister, Dr Aaron Motsoaledi's credit, five key other recommendations are now being championed at national level. These include task shifting from doctors to nurses in prescribing and initiating uncomplicated ARV treatment, co-management of HIV/TB by the same cohort of health care workers, vastly upscaled gold standard HIV/AIDS prevention methods, bringing big business into HIV testing, lobbying medical aids to absorb more patients at risk of HIV infection, and 'relentlessly' persuing the lowest possible ARV and opportunistic infection medicine prices available globally.

The two NGOs urged Finance Minister Gordhan to establish a Jali Commission (into price fixing by banks, 2006) look-alike body for the private health sector to ensure that prices were fairly set, transparent and did not create undue hardship in advance of the implementation of the National Health Insurance (NHI). They also honed in on Parliament's heel dragging in setting up a Parliamentary Budget Office (PBO) to monitor the proper and efficient manner in which financial resources are raised, allocated and spent.

The Money Bills Act (as required by the Constitution) for the first time provides Parliament with the statutory powers needed to fulfil its constitutional mandate regarding the budget. The NGOs said that, given the limited time frames in this Act and the complexity of the budget, there was not enough time to 'engage substantively' with Gordhan's 'Division of Revenue' Bill, as tabled. This had dire implications for the provinces which were reducing the contributions from their own coffers to the funding, e.g. of the HIV/AIDS, sexually transmitted infections (STIs) and TB programme, while the $\mathrm{NDoH}$ increased its funding of such provincially implemented programmes. The upshot was that activities not funded through the conditional grant continued to receive less money.

The NGO's budget analysis said the setting up of the PBO seemed dependent on unspent funds from Parliament's surplus account which it described as inadequate and dangerous' - given that a fully functional PBO by the 2012/2013 budget was 'crucial'.

\section{However, they urged Parliament, the National Treasury and the $\mathrm{NDoH}$ to 'fulfil their constitutional obligations' and provide oversight and assistance to provinces to 'ensure the end of poorly formulated budgets and an inability to track expenditure properly'.}

The NGOs welcomed Gordhan's additional funding for family health care teams, infrastructure and district-based maternal and child health services as 'vital for the revitalisation of this sector and in laying the foundations for the NHI'. However, they urged Parliament, the National Treasury and the $\mathrm{NDoH}$ to 'fulfil their constitutional obligations' and provide oversight and assistance to provinces to 'ensure the end of poorly formulated budgets and an inability to track expenditure properly'

\section{Eastern Cape rates well, Gauteng dismally}

NGO spokesperson Eager said the Eastern Cape's Health Director-General, Dr Siva Pillay, seemed to be a torch-bearer in 'making a fundamental shift in the way provinces do things'. While that province had experienced among the worst of the country's problems, it was ironically proving the most transparent in solving them via forensic and management audits and salary system audits. $^{3}$

'The question you need to ask is why Gauteng, which has the highest budget allocation, is doing so badly in delivery. There doesn't seem to be much honesty or critical reflection there. It seems that unless you have high level political backing to deal with these issues, the issues of who wins contracts and tenders and who is dishing them out, never get dealt with, he observed.

He believed the Hogan report was 'sat on because very little was being done to implement it. Maybe it's simply because the recommendations came during Hogan's leadership [Hogan, like another short-lived incumbent, Nozizwe Madlala-Routledge, was unpopular for her strong, independent views]'

'But it's quite difficult to understand, given that this blueprint is highly implementable, he stressed.

\section{Chris Bateman}

1. http://www.section27.org.za/wp-content/uploads/2010/06/ Consolidated-IST-Reportl.pdf (accessed 8 March 2011).

. Bateman C. 'Fix the damn system!' - Gauteng's tertiary hospital doctors. S Afr Med J 2011;101:152-156.

3. Bateman C. SmartPhones improving clinical outcomes. S Afr Med J 2011:101:12-13. 